University of Michigan Law School

University of Michigan Law School Scholarship Repository

Law \& Economics Working Papers

5-1-2019

\title{
Globalization, Tax Competition and the Fiscal Crisis of the Welfare State: A Twentieth Anniversary Retrospective
}

Reuven S. Avi-Yonah

University of Michigan Law School, aviyonah@umich.edu

Follow this and additional works at: https://repository.law.umich.edu/law_econ_current

Part of the Law and Economics Commons

Working Paper Citation

Avi-Yonah, Reuven S., "Globalization, Tax Competition and the Fiscal Crisis of the Welfare State: A Twentieth Anniversary Retrospective" (2019). Law \& Economics Working Papers. 159.

https://repository.law.umich.edu/law_econ_current/159

This Article is brought to you for free and open access by University of Michigan Law School Scholarship Repository. It has been accepted for inclusion in Law \& Economics Working Papers by an authorized administrator of University of Michigan Law School Scholarship Repository. For more information, please contact mlaw.repository@umich.edu. 
May 1, 2019

\title{
GLOBALIZATION, TAX COMPETITION AND THE FISCAL CRISIS OF THE WELFARE STATE: A TWENTIETH ANNIVERSARY RETROSPECTIVE
}

\author{
Reuven S. Avi-Yonah'1
}

\begin{abstract}
Twenty years ago I wrote "Globalization, Tax Competition, and the Fiscal Crisis of the Welfare State” (113 Harv. L. Rev. 1573 (2000)), which argued that " $[t]$ he current age of globalization can be distinguished from the previous one (from 1870 to 1914) by the much higher mobility of capital than labor... The mobility of capital is linked to tax competition, in which sovereign countries lower their tax rates on income earned by foreigners within their borders in order to attract both portfolio and direct investment. Tax competition, in turn, threatens to undermine the individual and corporate income taxes, which traditionally have been the main source of revenue ... for modern welfare states. The response of developed countries has been first, to shift the tax burden from (mobile) capital to (less mobile) labor, and second, when further increased taxation of labor becomes politically and economically difficult, to cut the social safety net. Thus, globalization and tax competition lead to a fiscal crisis for countries that wish to continue to provide social insurance to their citizens at the same time that demographic factors and the increased income inequality, job insecurity, and income volatility that result from globalization render such social insurance more necessary... This article argues that if both globalization and social insurance are to be maintained, it is necessary to cut the intermediate link by limiting tax competition in a way that is congruent with maintaining the ability of democratic states to determine the desirable size of their government." This paper reviews the development of tax competition in the subsequent two decades and argues that while it became worse in the period from 1998 to 2008, the financial crisis of 2008 and subsequent developments led to the enactment of promising limits to tax competition in OECD countries that in turn should enable them to strengthen the welfare state.
\end{abstract}

${ }^{1}$ Irwin I. Cohn Professor of Law, the University of Michigan. I would like to thank Yariv Brauner, Kim Clausing, Gianluca Mazzoni, Shay Moyal, Dan Shaviro, Fadi Shaheen... 


\section{Introduction}

The thesis of "Globalization, Tax Competition, and the Fiscal Crisis of the Welfare State"2 ("Globalization") was that the rise of tax competition for both portfolio capital and for direct investment weakened the ability of both developed and developing countries to maintain an adequate social safety net for their citizens, and that to maintain that safety net it was essential to place limits on tax competition. The thesis of this paper is that the financial crisis of 2008-9 led to further pressure on the safety net, and that in turn led to the enactment of meaningful limits to tax competition in OECD countries. In turn, such limits (and further limits that should be enacted) should make it possible to strengthen the safety net in the coming decade. The risk is that if this is not done, it will lead to a further rise in xenophobic nationalism, a retreat from globalization, and potentially to war.

\section{The Decline of the ITR, 1980-2008}

Before the 1980s, the international tax regime (ITR) functioned as an adequate protective device against tax competition and therefore protected the social safety net. The ITR is based on two principles, the benefits principle and the single tax principle. The benefits principle states that active (business) income should be taxed primarily by the source jurisdiction and passive (investment) income should be taxed primarily by the residence jurisdiction. The single tax principle states that the goal of the ITR is to prevent both double taxation and double non-taxation, and therefore that the secondary taxing jurisdiction (residence for active income and source for passive income) should impose tax in situation where the primary taxing jurisdiction does not do so. ${ }^{3}$

Before the 1980s, residence jurisdictions were able to impose tax on most passive income because exchange controls made it difficult to invest offshore, and because source jurisdictions imposed withholding taxes on such income. Active income was in turn taxed by source jurisdictions because it was less mobile, and CFC rules imposed residence-based tax on it in cases where it was more mobile and therefore escaped source-based taxation. ${ }^{4}$

As "Globalization" explains in detail, this situation changed in the 1980s and 1990s. Globalization led most countries to relax their exchange controls and

${ }^{2}$ Avi-Yonah, Globalization, Tax Competition, and the Fiscal Crisis of the Welfare State, 113 Harv. L. Rev. 1573 (2000).

${ }^{3}$ Avi-Yonah, International Taxation of Electronic Commerce, 52 Tax L. Rev. 507 (1997); Avi-Yonah, Who Invented the Single Tax Principle? An Essay on the History of US Treaty Policy, 59 NYLS L Rev 305 (2015).

${ }^{4}$ Globalization, supra. 
portfolio investments overseas became common. In addition, starting with the US in 1984, most OECD members unilaterally abolished withholding taxes on outbound interest payments, thereby aiding and abetting tax evasion by residents of other OECD members. For active income, the increased mobility of multinational enterprises (MNEs) led source jurisdictions to offer targeted tax holidays, and the fear of tax competition for headquarters of MNEs led residence jurisdictions to relax their controlled foreign corporation (CFC) rules. The result was that neither the residence jurisdiction of the multinational nor the production jurisdiction typically taxed its income on a current basis. The only jurisdiction that was not subject to this type of tax competition was the market jurisdiction, but after the creation of the Internet and the rise of the digital economy in the 1990s, it became possible for MNEs to earn billions in income from market jurisdictions without being subject to tax because of the permanent establishment limitation (which states that a country may not tax active income in the absence of a physical presence of the multinational). ${ }^{5}$

In the first decade after I wrote "Globalization" things only got worse. On the passive income front, it became possible to avoid withholding taxes not just on interest (because of unilateral abolition), royalties (because of the treaties) and capital gains (because of the source rules), but also on portfolio dividends because of the rise of derivatives, which enabled portfolio investors to receive the economic equivalent of the dividend without being subject to withholding taxes. In addition, it became clear that limits on the exchange of information such as bank secrecy, dual criminality, and the requirement that information only be exchanged on request meant that in most cases residence jurisdictions could not effectively tax foreign source portfolio income (earned primarily by the rich). In 2005, Joe Guttentag and I estimated that the US was losing $\$ 50$ billion a year to such tax evasion, and that most other countries were in worse shape because the shadow economy was larger. ${ }^{6}$

On the active income front, the decade 1998-2008 saw the enactment of check the box and IRC section 954(c)(6), which meant that the US CFC rules became incapable of enforcing residence based taxation of US-based multinationals. Deferral, which is defined as a tax expenditure in the US, exploded from less than $\$ 20$ billion in the mid 1990s to the second largest tax expenditure in the US budget, worth $\$ 1.348$ trillion for the decade 20172026. ${ }^{7}$ This was justified in the name of preserving the competitiveness of US-based MNEs, but it resulted in shifting of massive amounts of income

${ }^{5}$ Globalization, supra.

${ }^{6}$ Avi-Yonah, "Closing the International Tax Gap," in Max B. Sawicky (ed.), Bridging the Tax Gap: Addressing the Crisis in Federal Tax Administration (2005), 99 (with J. Guttentag).

7 US Treasury, Tax Expenditure Budget, 2017. 
from the US to low tax jurisdictions: By 2017 US MNEs had close to $\$ 3$ trillion in profits "trapped" in low-taxed jurisdictions offshore. Ireland, Luxembourg, and many other jurisdictions enacted low-tax regimes designed to attract such active income, as well as the headquarters of multinationals. Over thirty US-based MNEs "inverted" to Ireland and other low-taxed jurisdictions, primarily in order to reduce the US tax rate on US source income and to enable the distribution of low-taxed foreign-sourced income to shareholders. ${ }^{8}$

Thus, a decade after "Globalization", the problem it described was significantly worse than when it was written. Both the individual income tax (designed primarily to preserve progressivity) and the corporate income tax (designed primarily to regulate MNEs) were under tremendous pressure, and the resulting decline in revenues and the inability of most jurisdictions to raise consumption taxes (because they were already prohibitively high) meant that the social safety net was under severe pressure as well. And then came the financial crisis of 2008 and the Great Recession, and all hell broke loose.

\section{The Impact of the Great Recession: FATCA, CRS, BEPS, ATAP and TCJA}

On September 11, 2008, I was testifying before the US Senate Permanent Subcommittee on Investigations (PSI) on the ability of investors and investment banks to avoid withholding taxes on dividends by using derivatives, because dividend equivalents on derivatives were exempt from withholding tax. The PSI investigation discovered that even direct investors were avoiding the withholding tax by selling their shares to an investment bank the day before the dividend, receiving the dividend equivalent, and then buying the shares back the day after. The investors and the bankers were busy calling each other liars, and it was clear that both could not be telling the truth under oath. Suddenly, the witnesses started looking nervously at their Blackberries, and then scurrying out of the room: Lehman Brothers (which was one of the most active players in this scheme) had collapsed, and the financial crisis had started. ${ }^{9}$

${ }^{8}$ Avi-Yonah, Inversions and Competitiveness: Reflections in the Wake of PfizerAllergan, 41 Int'l Tax J. 39 (2015) (with O. Marian).

${ }^{9}$ This hearing led to the enactment of IRC section 871(m) in 2010, which imposed withholding tax on dividend equivalents. Avi-Yonah, Testimony on Dividend Tax Abuse, U.S. Senate Permanent Subcommittee on Investigations, Sept. 11, 2008; AviYonah, Enforcing Dividend Withholding on Derivatives, Shelf Project Proposal, 121 Tax Notes 747 (Nov. 10, 2008). 
The crisis and the Great Recession that followed led to millions losing their jobs and their homes, and frequently their families as well. Moreover, in Europe the governments reacted to the pressure on the Eurozone by imposing austerity and sharply cutting the social safety net. While the Obama Administration made no such cuts, and the Affordable Care Act was a meaningful move toward bolstering the safety net, the size of the US fiscal stimulus was too limited, and while the banks were saved millions of Americans suffered a decade of low growth and unemployment. ${ }^{10}$

The political reaction on both sides of the Atlantic was dramatic. It led directly to Brexit, the election of Donald Trump in the US and of other rightwing populists in the EU, and the prospect of serious limits to globalization in the form of immigration restrictions, tariffs, and the re-enactment of exchange controls. ${ }^{11}$ The nation state was reasserting itself, and one of the instruments it used was taxation. In the US the focus on taxation was limited to the first couple of years after the crisis, since the Republican takeover of the House in 2010 meant that no tax measures could be enacted before 2017. But in Europe austerity meant a continued political focus on taxing both the rich and MNEs. In the US, the "Double Irish Dutch Sandwich" was once described in detail in 2010 on the NBC Evening News, but the topic faded thereafter. In Europe, taxes became front-page matter for the whole period after 2008, and this political attention is still ongoing.

The result has been a series of developments that led to a significant enhancement in the ability of the ITR to capture cross-border income.

On the passive income front, a key development was the UBS scandal of 2006-8, which led directly to the enactment of FATCA in 2010. The UBS hearing before the PSI revealed that UBS sent bankers directly to the US to solicit rich individuals to set up shell companies in the Caymans and then reinvest the money through UBS into the US. UBS claimed that even though it was a "qualified intermediary" (QI) and knew who the real owner of the shells was, it was justified under the QI regulations in relying on a form W8BEN that stated that the owner of the income was the Caymans shell and that it was foreign. ${ }^{12}$

${ }^{10}$ Avi-Yonah, Be Careful What You Wish For: Reducing Inequality in the $21^{\text {st }}$ Century, 116 Mich.L. Rev. 1001 (2018) (with O. Avi-Yonah).

11 See Kim Clausing, Open: The Progressive Case for Free Trade, Immigration, and Global Capital (2019).

12 Avi-Yonah, Testimony on Banking Secrecy Practices and Wealthy American Taxpayers, US House Committee on Ways and Means, Subcommittee on Select Revenue Measures (March 31, 2009); Avi-Yonah, Testimony for Hearing on Offshore Tax Evasion, U.S. Senate Finance Committee (May 3, 2007); Avi-Yonah, Testimony for Hearing on Offshore Transactions, U.S. Senate Permanent Subcommittee on Investigations (Aug. 1, 2006). 
The result was the enactment of the Foreign Account Tax Compliance Act (FATCA) in 2010, which imposes a 30\% withholding tax on the US income of any foreign financial institution (FFI) that knows or has reason to know it holds accounts of US residents or citizens and does not reveal such information to the IRS. Because FFIs are frequently prohibited from directly revealing financial information to the IRS, the Obama Administration negotiated over 100 intergovernmental agreements (IGAs) that enable the FFI to turn over the information to its own government, which then exchanges it with the IRS under tax treaties and tax information exchange agreements (TIEAs). Many of the IGAs are reciprocal, so that the US is also obligated (at least on paper) to exchange information about foreign residents.

The IGAs in turn made countries develop a Common Reporting Standard (CRS) for the automatic exchange of financial information, and the OECD then negotiated a Multilateral Agreement on Administrative Cooperation in Tax Matters (MAATM), which relies on the CRS to provide for automatic exchange without the ability to rely on bank secrecy or dual criminality provisions. Most countries in the world, and all OECD members except the US have ratified the MAATM. ${ }^{13}$

The result has been that it is much more difficult to evade income taxation now than it was ten years ago. A potential evader has to worry that in almost every country information about her income may be collected and transmitted to her residence jurisdiction. In addition, she has to worry that the information may either be leaked by a whistleblower (as in the Panama Papers) or hacked (as in the Paradise Papers). I would estimate that FATCA alone has led to a significant decrease in the international tax gap in the US, well below my $\$ 50$ billion estimate from 2005 .

On the active income front, there have also been dramatic developments in the last decade. The first was the OECD Base Erosion and Profit Shifting (BEPS) project (2013-15), which was led by the G20 and resulted in fifteen action steps designed to enhance both source and residence based taxation of active income. For example, BEPS Action 2 bars a deduction for payments to hybrid entities, thereby eliminating the impact of check the box. ${ }^{14}$

${ }^{13}$ Avi-Yonah, And Yet It Moves: Taxation and Labor Mobility in the Twenty-First Century, 67 Tax L. Rev. 169 (2014); Avi-Yonah, IGAs vs. MAATM: Has Tax Bilateralism Outlived Its Usefulness? 66 CCH Global Tax Weekly 11 (Feb. 13, 2014) (with G. Savir). ${ }^{14}$ See Avi-Yonah, Evaluating BEPS: A Reconsideration of the Benefits Principle and Proposal for UN Oversight, 6 Harv. Bus. L. Rev. 185 (2016) (with H. Xu). 
BEPS was introduced in the EU as the Anti-Tax Avoidance Package (ATAP), which among other measures requires all $\mathrm{EU}$ members to adopt strict CFC rules (e.g., generally requiring residence-based taxation if the effective tax rate of the source jurisdiction is below $50 \%$ of the tax rate in the residence jurisdiction). This measure, in addition to the enactment of BEPS Action 2, means that it is much harder now to shift profits artificially out of EU member states. Another important measure in BEPS and ATAP is the primary purpose test (PPT), which requires that all tax treaties incorporate language that the treaty will not apply to transactions if a primary purpose of the transaction was tax avoidance. ${ }^{15}$

Until 2017, it could be argued that the US was a laggard in terms of combating tax avoidance, because it took the position that it was already compliant with BEPS, rejected the PPT, and did not sign the MAATM. But the 2017 tax reform (TCJA) dramatically changed that. TCJA includes three measures that significantly increase taxation of US-based as well as foreignbased MNEs. First, TCJA imposed a one time, hefty transition tax on the $\$ 3$ trillion of past, accumulated earnings of US-based MNEs. Second, while TCJA provided for an exemption for certain future dividends from CFCs to their US parents, this exemption is strictly limited to a deemed $10 \%$ return on tangible property, which for most US-based MNEs is close to zero (because they rely heavily on intangibles). For any amount that exceeds this deemed return, TCJA imposes a current minimum tax of 10.5\% (13.25\% if foreign tax credits are included) on worldwide earnings of the MNE. Third, TCJA imposes an alternative minimum tax of $10 \%$ on both US- and foreign based MNEs by disregarding interest, royalty and some other payments from the US to the related foreign entity. 16

The result of these developments (BEPS, ATAP ad TCJA) is that both US and foreign MNEs are likely to be subject to significantly higher levels of tax on cross-border active income than they were before 2008. ${ }^{17}$

To give an example: The structure used by most US-based MNEs before 2017 for their foreign operations was to have a top level CFC in a low-tax jurisdiction, with lower-tier CFCs in high tax jurisdiction. The parent would transfer intellectual property to the top CFC via a cost sharing agreement, and the top CFC would in turn would license the IP to the lower-tier CFCs. The key to this structure was that under check the box, only the top CFC would be treated as a corporation, while all the lower CFCs would be

\footnotetext{
${ }^{15}$ See Avi-Yonah, BEPS, ATAP and the New Tax Dialogue: A Transatlantic Competition? 46 Intertax 885 (2018) (with G. Mazzoni)

${ }^{16}$ Avi-Yonah, BEPS, ATAP, supra.

${ }^{17}$ See Clausing, Profit Shifting Before and After the Tax Cuts and Jobs Act (2019).
} 
disregarded (i.e., treated as branches of the top CFC) ${ }^{18}$ As a result, while for foreign tax purposes deductible royalties from the lower CFCs to the top CFC would be effective in shifting profits to the low-tax jurisdiction of the top CFC (and not subject to withholding under treaties), for US tax purposes these royalties did not exist and so did not trigger a deemed dividend to the US parent. In addition, deductible cost sharing payments could be made from the US parent to the top CFC.

This structure does not work any more, for three reasons. First, under BEPS Action 2, as implemented by the EU ATAP, the royalties from the bottom CFCs to the top CFC would not be deductible because they are to a hybrid entity. ${ }^{19}$ Second, the cost sharing payments from the US parent to the top CFC would be subject to the BEAT minimum tax. And finally, the top CFC as well as all the disregarded entities below it would be subject to the GILTI minimum tax (10.5\% or $13.25 \%$ with foreign tax credits) on a current basis. ${ }^{20}$ The result is that US-based MNEs need to restructure their foreign operations and are likely to be subject to a significantly higher worldwide effective tax rate than before 2018, despite the fact that both check the box and IRC section 954(c)(6) have not been affected by the TCJA.

\section{The Future: A Revival of the Welfare State or the End of Globalization?}

"Globalization" predicted that unless something was done about limiting tax competition, there would be a retreat from globalization and a revival of nationalism. This has now happened, in the form of restrictions on immigration and renewed tariffs and exchange controls. Increased nationalism could even lead to a new world war.

The last decade has seen significant limits to tax competition. But in order to prevent further political damage, more needs to be done. First, additional changes to bolster the ITR are required. Second, the added revenues should be used to bolster the social safety net and prevent another Great Recession.

There are three additional measures that I believe would strengthen the ITR.

1. In regard to passive income, despite CRS and MAATM, I do not think the solution can depend entirely on exchange of information and residence based taxation. There are too many residence countries to cooperate effectively, and there will always be some non-cooperative tax havens to attract evaders. But the key point is that portfolio investments are limited

${ }^{18}$ Under IRC 954(c)(6), the payments would not trigger a deemed dividend even if they were not disregarded.

${ }^{19}$ The same rule applies in the US after TCJA; see IRC $267 \mathrm{~A}$.

20 This assumes, as would be true in most cases, that the top CFC has no tangible assets that would entitle the parent to exempt dividends under IRC 245A. 
to a small number of large jurisdictions. If the US, EU and Japan could cooperate to re-institute withholding taxes on interest, a large part of the problem could be resolved. ${ }^{21}$

2. In regard to active income, there are a limited number of residence countries of MNEs (over 90 of the Fortune 100 are resident in the G20). If all the G20 could agree to further strengthen CFC rules to eliminate exemption or deferral, most MNE income would be taxed currently. ${ }^{22}$ In the US this would mean that the GILTI provision should be revised to eliminate the $10 \%$ deemed return exemption and increase the rate to $21 \% .^{23}$ Strict anti-inversion rules (e.g., a managed and controlled residency test) would eliminate the ability of MNEs to artificially move out of the US.

3. Since active income should be taxed at source, and since tax competition does not affect the market jurisdiction, the EU proposals for eliminating the PE standard and substituting a virtual PE threshold for "significant digital presence" should be adopted. ${ }^{24}$ In addition, a formula should be used to allocate residual profits under the arm's length standard between source jurisdictions. ${ }^{25}$ These ideas were both broached by the OECD and are likely to be adopted soon. The key issue is that the US and other G20 countries should grant foreign tax credits to such taxes. The fact that most G20 countries have similar tax rates should make such FTCs acceptable.

What should be done with the added revenues? I believe the first and necessary step would be to enhance the social safety net that was deeply hurt by the Great Recession. In the US, this requires universal health insurance, additional investment in education, and a massive infrastructure program.

In addition, I believe that steps need to be taken to enhance investment in those regions of the US that were left behind in the recovery from the Great Recession- specifically, the area between the Mississippi and the Appalachians. I have suggested that corporate job creation in this area be

21 Avi-Yonah, What Goes Around Comes Around: Why the USA is Responsible for Capital Flight (and What It Can Do About it), Haifa L. Rev. (2019).

${ }^{22}$ Avi-Yonah, "Hanging Together: A Multilateral Approach to Taxing Multinationals," in Thomas Pogge and Krishen Mehta (eds.), Global Tax Fairness, 113 (2016) 23 Clausing, Profit Shifting, supra.

${ }^{24}$ Avi-Yonah, The International Implications of Wayfair, 91 Tax Notes International 161 (July 9, 2018).

25 Avi-Yonah, Formulary Apportionment- Myths and Prospects, 3 World Tax J. 371 (2011) (with Ilan Benshalom); Avi-Yonah, Between Formulary Apportionment and the OECD Guidelines: A Proposal for Reconciliation, 2 World Tax J. 3 (2010); Devereux et al., Residual Profit Allocation by Income, WP 19/01 (March 2019). 
encouraged by a zero tax rate for profits allocated to it by a formula that hinges on job creation. ${ }^{26}$ While the individual income tax must be enforced to maintain progressivity, I would be willing to sacrifice most of the corporate tax if corporations could be induced to create jobs in the hinterland.

The world faces a crucial choice in the 2020s. We can either continue retreating from globalization in favor of xenophobic nationalism, tariffs, immigration restrictions, and exchange controls. That road leads ultimately to war, as it did in the 1930s. Or we can revive globalization by investing in a robust social safety net, infrastructure, education, and job creation. While more needs to be done, we have made significant progress in curbing tax competition in the last decade. The key move now is to take the added revenue and spend it wisely.

${ }^{26}$ Avi-Yonah et al., Bridging the Red-Blue Divide: A Proposal for Regional Tax Relief (2019), available on ssrn.

Error! Unknown document property name. 